\title{
Ayurvedic Treatment of Diabetic Retinopathy- A Review
}

\author{
Krishna Kumar $\mathbf{V}^{1^{*}}$, Dr. Vaghela D.B ${ }^{2}$, Dr. Manjusha .R ${ }^{3}$, Dr. Makhija $\mathbf{P}^{4}$ \\ ${ }^{1}$ Research Officer (Ayu), Regional Ayurveda Research Institute for Eye Diseases, Lucknow. \\ ${ }^{2}$ Associate Professor \& H.O.D in charge, Dept. of Shalakya Thantra, I.P.G.T.R.A, Gujrat Ayurved \\ University, Jamnagar \\ ${ }^{3}$ Professor and H.O.D, Dept. of Shalakya Thantra, All India Institute of Ayurveda, New Delhi. \\ ${ }^{4}$ Assistant Dirtector (Incharge), Regional Ayurveda Research Institute for Eye Diseases, Lucknow.
}

\begin{abstract}
:
Diabetic retinopathy (DR), the leading cause of visual disability in diabetics, is an important complication of diabetes mellitus (DM). Currently available conventional options for diabetic retinopathy have certain limitations; considering which options from alternative resources are being searched to meet the need. Ayurveda, the traditional system of Indian subcontinent hold huge number of remedies that can be useful in the treatment of diabetes and associated complications like diabetic retinopathy. To revalidate the actual efficacy of these formulations and treatment modalities in DR $(\approx$ Madhumehajanya Timira $)$; many studies have been carried out at different research centres of India. The present paper is a review of six such trials, two from I.P.G.T.R.A, Jamnagar, two from Kerala university of Health Sciences, and two from Rajiv Gandhi University of Health Sciences, Bengaluru. These studies aimed at establishing the impact of various Ayurvedic treatment modalities viz. Pancha Karma $(\approx$ purification/cleansing procedures $)$, Shamana $(\approx$ pacifying medicinal treatment) and Netra Kriya Kalpa $(\approx$ ophthalmic procedures $)$ in DR. These therapies were found to be significantly effective and clinically safe as no adverse drug reactions were reported during the treatment period. Ayurvedic approach is helpful in giving a complimentary treatment protocol for Diabetic retinopathy.
\end{abstract}

Key words: Diabetic retinopathy, Madhumehajanya Timira, Netra Kriya Kalpa, Pancha Karma, Rasayana, Shamana

\section{Introduction:}

Diabetic retinopathy (DR), the leading cause of visual disability in diabetics, is an important complication of diabetes mellitus (DM). ${ }^{1,2,3,4,5}$ The conventional treatment for DR is LASER Photocoagulation which just stops the leakage of blood and fluids in the retina, but doesn't break the root pathogenesis of DR. ${ }^{6}$ The use of intravitreal pharmacotherapies in the last decade has revolutionized the management of diabetic macular edema (DME) as well as proliferative diabetic retinopathy (PDR). But the heavy cost which has to be spent for each year with useful vision is too high for common man. Hence it is high time to address the issue of diabetes, prevention of its complications and management with all seriousness and find affordable medical care.DR and other diabetic ophthalmopathies which lead to poor vision can be taken under the concept of Madhumeha $\left(\approx\right.$ Diabetes mellitus) leading to Timira $\left(\approx\right.$ Defective Vision). ${ }^{7}$ Ayurvedic treatment targets upon destruction of pathogenesis from the root level; and for DR, its aims at nourishing Rasayanis $(\approx$ capillaries) enabling the self-maintenance of the system. ${ }^{8}$ Considering wide range of treatment modalities available for diabetic retinopathy in Ayurveda; $>10$ research works have been carried out at the level of MD and $\mathrm{PhD}$ at various Ayurvedic institutions all over India .The present paper is a review of six such trials, two from I.P.G.T.R.A, Jamnagar, two from Kerala university of Health Sciences, and two from Rajiv Gandhi University of Health Sciences, Bengaluru. 
Krishna Kumar $\mathrm{V}^{1^{*}}$, International Journal of Ayurvedic\& Herbal Medicine 8(3) May.-June. 2018 (3234-3240)

\section{Materials And Methods}

All the theses works have been collected from Department of Shalakya Tantra of respective universities. The procured theses were compiled and screened to assess the impact of Ayurvedic treatment modalities in DR.

\section{OBSERVATIONS}

\section{Stages of Diabetic Retinopathy}

DR can be broadly classified into- no apparent retinopathy, Non Proliferative Diabetic Retinopathy (NPDR) - mild, moderate and severe and Proliferative Diabetic Retinopathy (PDR) ${ }^{9}$. It was observed that three studies were conducted on NPDR, one on PDR and rest two included all stages of Diabetic retinopathy.

\section{Poorva Karma ( $\approx$ pre-operative procedures) in Diabetic Retinopathy}

Deepana Pachana $(\approx$ stomachic and digestant) was done with Trikatu Churna or Chitrakadi Vati in the study by Haripriya et. al. In the study by Priyankarani et. al., Snehapana ( $\approx$ internal administration of medicated ghee) was done with Triphala Ghrita followed by Swedana ( $\approx$ Sudation). Trikatu Churna was used for Deepana Pachana.

\section{Pancha Karma in Diabetic Retinopathy}

Virechana $(\approx$ Purgation) was done in two studies. A compound of Triphala (Terminalia chebula Retz., Embilica officinalis Gaertn and Terminalia bellerica Roxb), Trivrita (Operculina tarpethum Linn) and Katuki (Picrorhiza kurroa Royle ex benth) Powder in a ratio of 2:1:1 was used for Virechana in the study by Priyankarani et. al. and in the study by Haripriya et. al., Koshta Shodhana (purgation without prior oleation) was done with Kwatha (Decoction) prepered out of a compound containing Draksha (Vitis vinifera Linn- dried fruit), Taruni pushpa (H. Rosa sinensis Linn- flower ), Hareetaki (Terminalia chebula Retz- dried fruit.) and Aragwadhamajja (Cassia fistula Linn -fruit pulp) taken in equal quantity.

Nasya ( $\approx$ Nasal medication) was done in two studies. In the study by Haripriya et. al Shodhana Nasya was done by Pippali (powder of Piper longum Linn)and Saindhava (Rock salt) Avapeeda $(\approx$ purificatory Nasya)for 1-3 days which was followed by Marsha Nasya (oleating Nasya in large dose)with Drakshadi Ghrita for seven days. In the study by Vinitha. T.V et. al., Sthambana ( $\approx$ hemostatic) Nasya with Durva Swarasa (expressed juice of leaf of Cynodon dactylon Linn) mixed with equal quantity of Aja Ksheera (Goat's milk) was done for seven days (dose according to the patient).

Pratimarsa Nasya ( $\approx$ Nasal medication in mild dose ) was done in four studies. In the studies by Priyankarani et. al. and Vinitha.T.V et. al. Anu Taila was used. Draksadi Ghrita was used in the study by Haripriya et. al. In the study by Manu.V.K et. al., Durva Swarasa was administered in 2 bindu dose each nostril for 41 days. In the same study, Ksheerabala Taila 7 Avarthi ( $\approx$ potentiated seven times) was used in control group.

\section{Shamana in Diabetic Retinopathy}

Mahavasakadi Kwatha (50 $\mathrm{ml}$ in morning for 48 days) was compared to Tarpana ( $\approx$ retention of medicated ghee over eyes) with Doorvadya Ghrita by Adoor et. al. In another study by Bhavya. B.M et. al., Vaasadi Kwatha was compared to Takradhara ( $\approx$ pouring medicated buttermilk over the scalp) and Anjana $(\approx$ ocular ointment) with Tuvarakadi Anjana. Shamana Snehapana with Mahatriphala Ghrita was done for 15 days in the study by Vinitha.T.V. et. al.

\section{Rasayana ( $\approx$ Rejuvenating drugs) in Diabetic Retinopathy}

Rasayana Yoga containing Nisa (Curcuma longa Linn), Amalaki (Embilica officinalis Gaertn.), Guduchi (Tinospora cordifolia Thunb Miers) and Musta (Cyprus rotundus Linn) was given 5 gm bd with Madhu (honey) and Ghrita (ghee) for 2 months in the study by Priyankarani et. al.. In the study by Haripriya et. al., Bala (Abutilon Indicum), Yashtimadhu (Glycerrhiza glabra Linn), Bhringaraja (Eclipta alba Linn) and Vasa (Adathoda vasica Nees) were added to the previous Yoga (formulation) and given $3 \mathrm{~g}$ bd with Madhu.

\section{Netra Kriya Kalpa in Diabetic Retinopathy}

Tarpana was done only in one study with Doorvadya Ghrita. [Three sittings, five days in each sitting, gap of 11 days after each sitting, total 48 days] by Adoor et. Al. Anjana was done in two studies. Chandanadi Varthi mixed with honey was used for one month as Anjana followed by Kshalana ( $\approx$ eye wash) with Yashti 
Krishna Kumar $\mathrm{V}^{1^{*}}$, International Journal of Ayurvedic\& Herbal Medicine 8(3) May.-June. 2018 (3234-3240)

Darvi Kwatha (Decoction prepared from Glycyrrhiza glabra Linn and Berberis aristata DC) in the study by Vinitha. T.V et. al. .In the study by Bhavya.B.M et. al. Tuvarakadi Anjana was used for five days with a gap of one week, four sittings.

\section{Application of Moordha kriyakrama in Diabetic Retinopathy}

Treatment procedures like Takradhara which are done on the scalp may be termed Moordha Kriyakrama. Takradhara was done in studies by Priyankarani et. al. and Bhavya .B.M et. al. Shirolepa (application of medicated paste on scalp) was done with Mukkadi Bidalaka Yoga in two studies. In the study by Haripriya et.al. it was done once daily for 21 days, two sittings. In the study by Vinitha.T.V et. al. it was done for seven days. In the same study Shirodhara was done with Mridweekadi Ksheera Kashaya $(\approx$ decoction prepared by adding milk) for seven days following Shirolepa. Also Talam (application of medicated paste over Bregma) of Kseerabala Tailam and Kachooradi Choorna was done for seven days in this study.

\section{RESULTS :}

\section{Trial 1-}

A Clinical study to evaluate the role of holistic Ayurvedic treatment in Premehaja Timira w.s.r Background Diabetic Retinopathy - Priyanka rani, K.S.Dhiman, Manjusha R, Anup Thakar, Hitesh Vyas et al- The trial group had better results than control group.

\section{Trial-2}

Further Clinical Study on Pramehajanya Timira (Background Diabetic Retinopathy) \& its Ayurvedic Management-: Haripriya. H, K. S. Dhiman, Hitesh Vyas et al- The trial group had better results than control group.

\section{Trial-3}

The efficacy of Ayurvedic management in Proliferative diabetic retinopathy -A randomised controlled trialVinitha T V, Sreeja Sukesan, Kusumam Joseph, S. R. Krishnamoorthy et al- The treatment protocol adopted was found to be effective than control group in improving and maintaining vision stable, in reducing floaters, in relieving erythropsia, in decreasing vitreous hemorrhage, in clearing fibrosis. Control group was found to be more effective in reducing pre retinal hemorrhage and bringing about regression of new vessels

\section{Trial-4}

Effectiveness of Durva Swarasa Pratimarsa Nasya in retinal haemorrhages associated with Nonproliferative diabetic retinopathy- Manu.v.k, S.Sunil Kumar, Kusumam Joseph et al-The comparison made between Durva Swarasa and Ksheerabala 7 Avarthi suggested that Durva Swarasa is relatively immediate in controlling intraretinal hemorrhages.

\section{Trial-5}

Management of diabetic retinopathy with Doorvadya Ghrita Tarpana and internal administration of Mahavasadi Kwatha-a comparative study Adoor Veeranagouda, B N Ramesh et al- Although all the three groups had statistically significant results, Mahavasakadi Kwatha had better response compared to Tarpana with Doorvadya Ghrita and also than combined treatment. Tarpana showed better response than combined treatment.

\section{Trial-6}

A comparative study on Takradhara and Vaasakadi kwatha orally in the management of Diabetic retinopathy - Bhavya.B.M, Ramesh et. al.- Although all three groups showed statistical significant result, Vaasadi Kwatha showed overall higher significance and better response followed by Takradhara and Anjana respectively.

\section{DISCUSSION}

All the six researches were clinical studies. Different therapeutic modalities used in these studies are depicted in [Figure 1]. References of drugs used in these studies are enlisted at [Table 1] 
Figure-1 Therapeutic modalities used in different studies

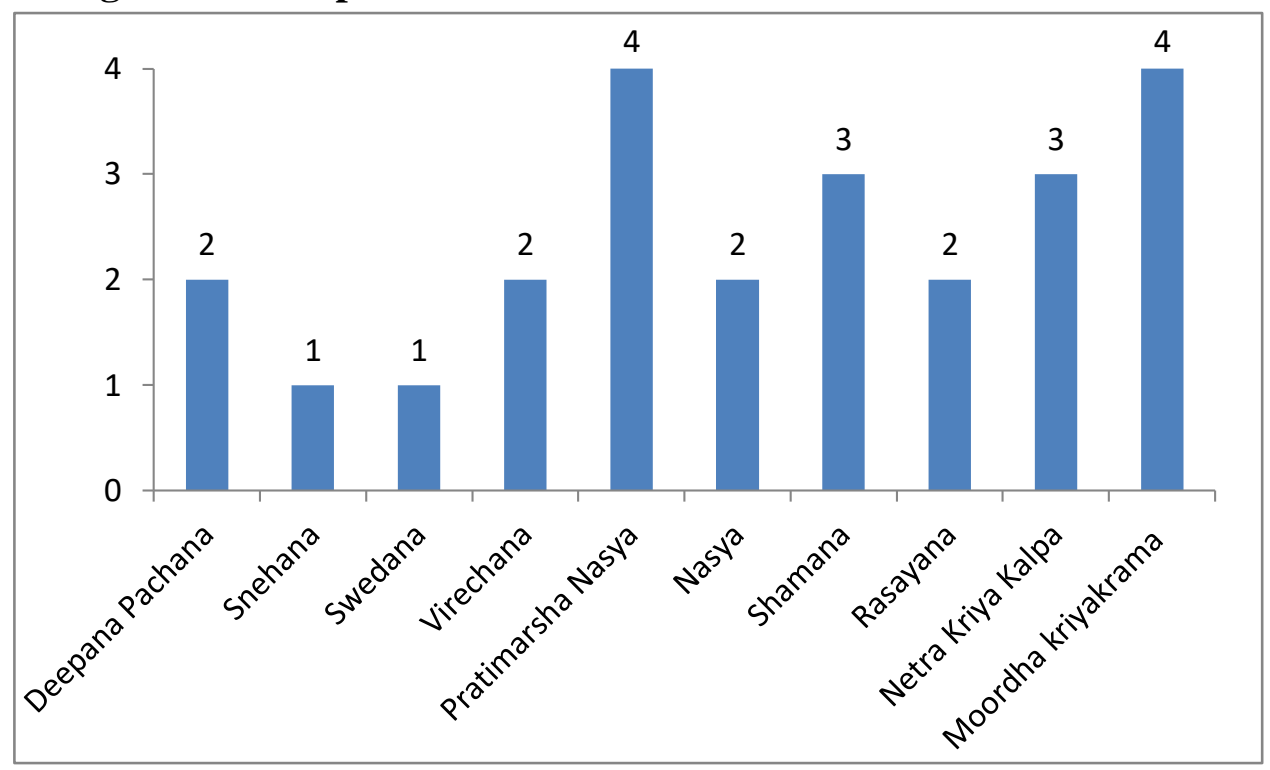

Table-1 References of Drugs used in different studies

\begin{tabular}{|l|l|}
\hline Trial Drug & Reference \\
\hline Trikatu Churna & $\begin{array}{l}\text { Sharngadhara Samhita Madhyama Khanda } \\
\text { Churnakalpana 6/12 }\end{array}$ \\
\hline Chitrakadi Vati & Charaka Samhita Chikitsa sthana 15/35-36 \\
\hline Triphala Ghrita & $\begin{array}{l}\text { Sharngadhara Samhita Madhyama Khanda } \\
\text { Snehakalpana 9/67-71 }\end{array}$ \\
\hline Drakshadi Ghrita & Ashtanga Hridaya Uttarasthana 13/ 4-5 \\
\hline Anu taila & Ashtanga Hridaya Sutrasthana 20/37,38 \\
\hline Ksheerabala taila & Ashtanga Hridaya Chikitsasthana 22/45-46 \\
\hline Mahavasakadi kwatha & Yogaratnakara Netraroga \\
\hline Mahatriphala Ghrita & Ashtanga Hridaya Uttarasthana 13/12,13 \\
\hline Chandanadi Varthi & $\begin{array}{l}\text { Arogya Raksha Kalpa Druma Netraroga } \\
\text { chikitsa, 26 }\end{array}$ \\
\hline Tuvarakadi Anjana & Susruta Samhita Chikitsa Sthana 13/34-35 \\
\hline Mukkadi Yoga & Sahasrayoga Netraroga Prakarana \\
\hline Mridweekadi Kashaya & Sahasrayoga Netraroga Prakarana \\
\hline Kachooradi Churna & Sahasrayoga Choorna Prakarana \\
\hline
\end{tabular}

Most of the works were done on NPDR. It may be because of the fact that the prevalence of NPDR is more as compared to other stages of DR10. Poorva Karma in the form of Deepana Pachana is included in two studies and Snehana ( $\approx$ oleation) in the form of Snehapana only in one study. In a Prameha Rogi (diabetic patient), there will be increased Kapha, Meda and Mamsa which are contraindication for Snehana.11 This may be the reason why Snehana was not done in most studies. Acharya Vagbhata has stated that if Snehana to be done in above said conditions, it should be preceded by Rookshana ( $\approx$ dehydrating) 12 . This Rookshana was attained by drugs used for Deepana Pachana. Swedana is done in only one study as Prameha is Aswedya (Sudation contraindicated) 13

Virechana and Nasya are the two Shodhana procedures preferred in these works. Virechana is indicated in Prameha, Urdhwaga Raktapitta (bleeding through upper orifices of body) and Timira.14 Moreover, as the features of Madhumehajanya Timira are similar to Urdhwaga Raktapitta; Virechana was 
Krishna Kumar $\mathrm{V}^{1^{*}}$, International Journal of Ayurvedic\& Herbal Medicine 8(3) May.-June. 2018 (3234-3240)

used as Pratilomahara chikitsa.15. Chakshsushya Vasti (medicated enema) which has got indications in Raktapitta, and which is Chakshushya ( $\approx$ congenial to eyes) 16 is also an apt procedure for the disease. Nose is the gateway of drug administration in diseases of head. Hence different Yogas have been tried for Nasya in different stages of DR. Most of the drugs were having Raktapittahara properties which help in absorption of retinal haemorrhages. Some of the drugs like Anutaila and Pippali and Saindhava Avapeeda Nasya have Srotoshodhana $(\approx$ clearing of channels in head and eyes) and Kaphanirharana ( $\approx$ elimination of Kapha) properties taking into consideration of Kapha predominance in the early DR. Pratimarsha Nasya was considered in most studies may be because it causes Srotovisudhi 17 and Indriya dridatha $(\approx$ imparting strength to eyes) 18

All the Shamana Yogas like Mahavasakadi Kwatha, Vasaadi Kwatha and Mahatriphala Ghrita have Raktapitta hara (hemostatic) properties. Most of the drugs present in Rasayana Yoga have Chakshusya and Pramehahara $(\approx$ hypoglycemic) properties. They also act by strengthening the Rasayanis which are weak by virtue of disease.

Among the seven Netra Kriya Kalpas explained in classics, Tarpana and Anjana were tried in these studies. Other Netra Kriya Kalpas like Vidalaka (application of medicated paste over eyelids, Seka ( ocular irrigation) and Putapaka (retention of medicine over eyes) would be tried in future research works.

Takradhara, Takra Shirolepa, Shirodhara and Talam were done in different studies as Moordha Kriya Krama. In addition to the effect of the medicaments used, these procedures are reported to produce a mental relaxant effect also which will help to reduce stress in patients.

\section{Conclusion:}

In nutshell, all Ayurvedic therapies were found to be significantly effective and clinically safe as no adverse events of adverse drug reactions were reported during treatment period. When used along with conventional drugs; no interactions were reported in any study. Thus by these virtues the Ayurvedic approach is helpful in giving a complimentary treatment protocol for Diabetic retinopathy. Chakshushya Vasti, Vidalaka, Seka and Putapaka would be incorporated in future research works to revalidate their efficacy in DR.

\section{Acknowledgement:}

I would like to sincerely thank my co-authors Prof. Manjusha R, Dr.D.B.Vaghela. and Dr. Pratap Makhija for their valuable guidance and understanding. I would like to extend my gratitude to Prof.Vd.K.S.Dhiman, Director General, CCRAS. I would like to extend my gratitude to Dr.Deepak.K.Pawar, Assistant professor, Dept. of Shalakyathantra, I.P.G.T. \& R.A. Jamnagar, for his constant support. I would like to acknowledge Dr. Sreeja Sukesan, Professor, Govt. Ayurveda college, Tripunithura, Dr.S.Sunil Kumar, Professor, Govt. Ayurveda college, Thiruvananthapuram, Dr. Kusumam Joseph, Associate Professor,Govt . Ayurveda college, Thiruvananthapuram, Dr.B.N Ramesh, Dr.Anup.B.Thakar, Dr.Hitesh Vyas, Dr.Vinita.T.V, Dr.Priyanka Rani, Dr.Haripriya.H, Dr. Veeranagouda Adoor, Dr.Bhavya.B.M and Dr.Manu.V.K.'

\section{References:-}

1. Danaei G, Finucane MM, Lu Y, Singh GM, Cowan MJ, Paciorek CJ, et al. National, regional, and global trends in fasting plasma glucose and diabetes prevalence since 1980: Systematic analysis of health examination surveys and epidemiological studies with 370 country-years and 2.7 million participants. Lancet 2011; 378:31-40.

2. World Health Organization. Global Health Risks. Mortality and Burden of Disease Attributable to Selected Major Risks. Geneva: World Health Organization; 2009.

3. Mathers CD, Loncar D. Projections of global mortality and burden of disease from 2002 to 2030. PLoS Med 2006;3:e442.

4. World Health Organization. Global Status Report on Non Communicable Diseases 2010. Geneva: World Health Organization; 2011. 
5. Shaw JE, Sicree RA, Zimmet PZ. Global estimates of the prevalence of diabetes for 2010 and 2030. Diabetes Res Clin Pract 2010;87:4-14.

6. Aiello LM. Perspectives on diabetic retinopathy. Am J Ophthalmol 2003; 136: 122-35.

7. Netraprakashika, first edition, 1999, Netra prakashika by Pujyapada Mahamuni, Kendriya Ayurved and Siddha Anusandhana Parishad, New Delhi. chaturthapatala, P 12

8. Acharya YT, editor. Sushruta Samhita of Sushruta, Chikitsa sthana, Pramehapidaka chikitsa, chapter 12, verse 8, Chaukhambha Surbharati Prakashan; Varanasi: reprint 2017; 454.

9. Wilkinson CP, Ferris FL 3rd, Klein RE, Lee PP, Agardh CD, Davis M, Dills D, Kampik A, Pararajasegaram R, Verdaguer JT, Global Diabetic Retinopathy Project Group. Ophthalmology. 2003 Sep; 110(9):1677-82.

10. Yau JW, Rogers SL, Kawasaki R, Lamoureux EL, Kowalski JW, Bek T, Chen SJ, Dekker JM, Fletcher A, Grauslund J, Haffner S, Hamman RF, Ikram MK, Kayama T, Klein BE, Klein R, Krishnaiah S, Mayurasakorn K, O'Hare JP, Orchard TJ, Porta M, Rema M, Roy MS, Sharma T, Shaw J, Taylor H, Tielsch JM, Varma R, Wang JJ, Wang N, West S, Xu L, Yasuda M, Zhang X, Mitchell P, Wong TY, Meta-Analysis for Eye Disease (META-EYE) Study Group. Diabetes Care. 2012 Mar; 35(3):556-64.

11. Charaka Samhita Sutra Sthana 13/14, Carakasamhita-Elaborated by Charaka and Dridhabala with the Ayurveda - Dipika commentary by Chakrapanidatta, edited by Vaidya Jadavaji Trikamji Acharya, 5th ed. Varanasi: Chaukhamba Surbharati Prakashan; Reprint 2000. 738 P 82

12. Astanga Samgraha Sutra Sthana 25/65, Deepika commentary by Ragahvan tirumulpad, 3rd edition, Prakashika publication, 2010, p 35

13. Astanga Samgraha Sutra Sthana 26/28, Deepika commentary by Ragahvan tirumulpad, 3rd edition, Prakashika publication, 2010, p 54

14. Astanga Samgraha Sutra Sthana 27/9, Deepika commentary by Ragahvan tirumulpad, 3rd edition, Prakashika publication, 2010, p 66

15. Harishastri P, editor. Ashtanga Hridayam of Vagbhata, Nidana sthana; Raktapitta kasa nidana, chapter 3, verse 14. Chowkhambha Surbharati Prakashan; Varanasi: reprint 2017; 468.

16. Harishastri P, editor. Ashtanga Hridayam of Vagbhata, Kalpa Sthana; Vastikalpa, chapter 4, verse 28. Chowkhambha Surbharati Prakashan; Varanasi: reprint 2014; p 757.

17. Astanga Samgraha Sutra Sthana 29/17, Deepika commentary by Ragahvan tirumulpad, 3rd edition, Prakashika publication, 2010, p 159

18. Harishastri P, editor. Ashtanga Hridayam of Vagbhata, Sutra sthana; Nasya vidhi, chapter 20, verse 29. Chowkhambha Surbharati Prakashan; Varanasi: reprint 2017; p 292. 